\title{
Taxonomy and palaeobiogeography of the Cenozoic Euro-Mediterranean rissoid gastropod Galeodinopsis and its relationship with close genera
}

Vittorio Garilli and Daniela Parrinello

Acta Palaeontologica Polonica 59 (2), 2014: 379-406 doi: http://dx.doi.org/10.4202/app.2012.0044

The investigation of the Late Paleogene to Late Neogene species of rissoid gastropod Galeodinopsis in the Euro-Mediterranean area has supported the hypothesis that this genus is an intermediate form between two well-known rissoids, Alvinia and Manzonia. We recognized four species of Galeodinopsis: G. biangulata, G. germanica sp. nov., G. semperi (new name for Rissoa duboisii), and G. tiberiana. The oldest (very Late Eocene/Oligocene) representatives of Galeodinopsis, G. biangulata and G. semperi, share similar shell shape and microsculpture with Alvinia. This suggests that Galeodinopsis originated from some Eocene species related to Alvinia . The new species represents the first occurrence within Galeodinopsis of a combination of characters very close to those of Manzonia, above all the typical pitted microsculpture.

We hypothesize that Manzonia evolved from Galeodinopsis rather than from the genera Alvania or Alvinia, as previously supposed. Galeodinopsis originated during the very Late Eocene/Oligocene in the North Sea Basin. Afterwards it underwent a strong southward shift to the mid-high east Atlantic and the Mediterranean area, during the Mio-Pliocene, and to the Recent tropical eastern Atlantic coasts, where the type species $G$. tiberiana still lives. The shift likely was due to a combination of climate cooling and palaeogeographical changes. The distribution of G. biangulata suggests that connections between the North Sea Basin and the Atlantic domain opened through the Channel area at least during the Early Oligocene, earlier than indicated previously. The distribution of Manzonia moulinsi supports the idea of a southern connection to the Atlantic Aquitaine Basin via the Rhine Graben during the Late Oligocene. From a palaeoecological point of view, Galeodinopsis includes warm species with planktotrophic larval development that are typical of the shelf environment in fully marine conditions.

Key words: Gastropoda, Rissoidae, taxonomy, palaeogeography, biogeography, Cenozoic, North Sea, Atlantic connection, Europe.

Vittorio Garilli [vittoriogarilli@apema.eu], APEMA Research and Educational Service, Via Alla Falconara 34, 90136 Palermo, Italy; Daniela Parrinello [daniela.parrinello@unipa.it], Facoltà di Scienze della Formazione, University of Palermo, Via Archirafi 18, 90100 Palermo, Italy. 
This is an open-access article distributed under the terms of the Creative Commons Attribution License (for details please see creativecommons.org), which permits unrestricted use, distribution, and reproduction in any medium, provided the original author and source are credited.

FoF Full text $(2,008.1 \mathrm{kB})$

For 5 Supplementary file $(103.5 \mathrm{kB})$ 